\title{
Jokowi's Political Communication in Jakarta Governor Election to Win Age-Based Voters
}

\section{Dr. Eko Harry Susanto}

\author{
Faculty of Communication, Tarumanagara University, Jakarta, Indonesia
}

Email: ekos@fikom.untar.ac.id

\author{
Doi:10.5901/mjss.2017.v8n1p312
}

\begin{abstract}
The Jakarta governor election year 2012 - 2017, became one of the benchmarks of political dynamics in Indonesia. In strict competition on the first round of gubernatorial elections, followed by the six candidates for governor and Deputy Governor. But because there was no candidates that reached at least 50 percent +1 vote, the election of the second round were conducted, followed by Fauzi Bowo - Nachrowi Ramli, and the candidates Joko Widodo - Basuki Tjahaja Purnama. The purpose of this study is to determine the pattern of political communication and the characteristics of voters, voter orientation based on age, and analyse the main contributor voter for Jokowi. This study uses a qualitative methodology, to describe the collected data about political communication in the gubernatorial election. The findings of this study is that there are different patterns of political communication between candidates couple for governor when interacting to confront with voters based on productive age in the community. But substantively, pragmatic group was 30-39 years, and the $X$ generation of 17-29-year-old was the determination of Jokowi's winning as Jakarta governor.
\end{abstract}

Keywords: political communication pattern, voter's orientation, working group characteristics, Indonesian political. Jokowi's winning

\section{Introduction}

Competition between candidates couples in the elections for governor of Jakarta is a real picture of the dynamics of political communication that characterize the political reformation era in Indonesia. Each pair of candidates for governor and Deputy Governor explained brilliant program despite in the normative frame and clichés.

Among the six candidates for governor and Deputy governor, according to the Lingkaran Survei Indonesia polling, which was presented on 8/4/2012, , Fauzi Bowo and Nachrowi Ramli, who is often called Foke - Nara, gained 49,1 percent of the votes. Followed by Joko Widodo and Basuki Tjahaja Purnama, with Jokowi - Ahok brand, was at the second rank, with 14,4 percent of the votes. Furthermore, in the third position, Hidayat Nur Wahid - Didik Rachbini candidates couple got 8,3 percent. Consecutively on the fourth to the sixth position, Faisal Basri-Biem Benjamin $(5,8$ percent), Alex Noerdin-Nono Sampono (3,9 percent) and Hendardji Soepandji-A Riza Patria candidates copules, who only received (1,2 percent). (http://news.detik.com)

However, based on votes counting on General Election of Governor and Deputy Governor of Jakarta in 2012, the first round on July 11, 2012, Jokowi-Ahok got 1.847 .157 votes or by 42,60 percent. Duet Foke-Nara who expect to win one round, only gain 1.476 .648 votes, or by 34,05 percent. The third position was occupied by fourth ranking, namely Hidayat-Didik, by a vote of 508.113 , or by 11.72 percent. (http://megapolitan.kompas.com)

Meanwhile, Faisal-Biem candidate couple was is in the fourth position, with 215.935 , or 4,98 percent votes. While Alex-Nono candidates couple got 202. 643 or by 4,67 percent votes. The last position was occupied by Hendardji-Riza, by 85.990 or 1,98 percent votes. The results of various polls that are different from the reality of the first round of gubernatorial elections implementation, indicating speculation the Jakarta election winner is not easy. For those candidates have the strength to compete individually, as well as the support of diverse groups (Susanto in Susanto, 2010: 70)

Entering the second round held in September 20, 2012 Foke - Nara candidates couple, and Jokowi - Ahok, using different campaign strategies. Various group of people identifies it as a war of ideology, compete the program forcefulness, or competition between the status quo by those who want a change.

If referring to political calculations, in fact Foke- Nara candidates couple was supported by many political parties could be distinguished than Jokowi- Ahok. In the 2009 election, the Democratic Party (Partai Demokrat) won the legislative election in Jakarta, with the acquisition of 33 percent of the votes. PKS (Partai Keadilan Sejahtera) in second position with 17 percent of the votes, add with Partai Golkar, Partai Persatuan Pembangunan, Partai Hati Nurani Rakyat and the Partai Kebangkitan Bangsa. Total parties who supported Foke - Nara were about 70 percent. Compare with 
Jokowi - Ahok, which supported by the Partai Demokrasi Indonesia Perjuangan (PDIP), which only gets 10 percent, and Partai Gerindra 5 percent. But it turns out that couple with this minimal party support, win (Tempo Newspaper Editorial, September 21, 2012)

Can not be denied, that constituents supports in Jakarta gubernatorial election is not associated with the support of political parties in Jakarta Regional House of Representatives. Therefore, various winning analysis of Jokowi - Ahok appears, will enrich the dynamic political communication study in local and national political competition.

The final results of Jakarta gubernatorial election in 2012, the second round, suggesting that Jokowi- Ahok candidates couples originally was estimated underdog actually gained the victory as Governor and Deputy Governor of Jakarta. Based on the votes count conducted by Jakarta Regional Election Commission, this Governor and Deputy Governor candidates couple get $53,82 \%$ of the votes. This is equivalent to 2.472 .130 million votes. Jokowi-Ahok surpass Fauzi Bowo-Nachrowi Ramli who obtained $46,18 \%$ of votes (2,120,815 voters). (http://sidomi.com)

\section{Conceptual Framework}

To support the discussion of the topic, the following are relevant concepts.

\subsection{Political Communication}

In the perspective of Nimmo (2005: 8), "Political communication is communication that refers to political activities". Thus every conversation containing political aspects, can be grouped into political communication, albeit merely discussing a state of power, without directly involved in activities of a political party or political group in the society. Meanwhile, other opinion says "Political communication is a process of mass communication including interpersonal communication and the elements in it that may have an impact on political behaviour". (Krans and Davis, 1976: 7).

With the same substance, Rush and Althoff, (1997: 225) argues that political communication is the transmission of information that is politically from one part of the political system to other political system, and between social systems and political systems which are dynamic elements of a political system, In Nimmo's opinion (2005: 47), components in political communication are: (1) political communicator, is someone who has the ability in political communication. (2) political message, associated with political messages and political information about the various power and its influence in the community, the authority owned and the political conflict in the competition involving the public, political institutions, government and political entities (3) The media of political communication, as a means to send a political message, (4) Audience of political communication established through public opinion by political communicator (5) Impact of communication in politics, which is a consequence of political socialization conducted by political communicator, which results in political learning and political participation of the community.

\subsection{Communicators, Messages and Audiences}

Communicators, messages, media, and the public are decisive factors in the political competition as the general election. In order to achieve excellence not only the politicians competing achievement but how to organize messages properly in order to reach the prospective voters. Messages should be the results of the final results that have been tested in terms of value or quality and effectiveness in achieving the target.

Message testing is a process of encoding that is projected into the reasoning power capability of the recipient of the message. The encoding process is a process of selecting an alternative that relates to the right symbol, the contents of which are easily digested and normative touch estimation that allows messages that can be actualized into everyday practice (SP, Varma, 2003: 373). Political message attached to an element of the campaign should be a major concern for the influence of diverse constituencies based on socio-cultural, economic and other demographic aspects. Therefore the substance of the message will reflect the aspirations, views, ideas or opinions that thrive in a pluralistic society.

Correspondingly, Venus suggests that a campaign is always preceded by the appearance of a particular idea that is constructed in the form of a message to be delivered to the audience. This message will be perceived, addressed, accepted or rejected by the audience. Hence the core of the campaign is none other than a message (Antar Venus, 2004: 70).

Furthermore, Schramm (1955), set four conditions for the success of a message namely (1) the message should be planned and can attract the attention of the audience; (2) use of a mark that is already known by communicator and audience that forming similarity of meaning; (3) capable of generating personal needs and (4) provide a way to obtain adequate for the needs of the audience. Results from the first study of Carl I Hovland, Arthur A. Limsdale, and Fried D. 
Sheffield (in Arifin, 1998: 58), concluded that the presentation of the message that is both side issue more effectively carried out to audiences who disagree with communicators and to educated people. In contrast, the one side issue presentation is more effectively provided to the audience who agree with the communicator or to the uneducated audience.

Essentially, the message has a strong influence to the public if it is organized according to the needs of audiences and provide benefits to the recipient of the message. Therefore David Berlo (in Ruben, 1992: 33) confirms that the message to the audience must consider aspects of communication skills, attitudes, knowledge, social and cultural systems. In the context of this similarity of behaviour, characteristics, and an introduction to the symbol of communication that are able to build shared meaning need to be considerate by communicators who seek to influence the audience.

\section{Problems of Research}

This study is attempts to analyse the strength of two candidates couples of Jakarta governor, seen from the efforts of both candidates in exploring symbols of strength, and patterns of communications to constituents segmented into age groups. Lingkaran Survei Indonesia released the results of a survey related to the General Election of Governor of Jakarta. As a result, either one or two rounds, the incumbent couple, Fauzi Bowo and Nachrawi Ramli has the greatest likelihood of winning the election for governor of Jakarta by more than 50 percent scores. (http://megapolitan.kompas.com). Estimation of Foke - Nara winning in one round, because this couple is very popular, supported by 137 community organizations and non-governmental organizations that are preparing to win in one round. (http://otomotif.kompas.com)

The survey results of private television in Jakarta Televisi (JakTV) shows the couple Foke-Nara will win in one round, gaining 53,78 percent. Jokowi got 29,61 percent, and the other candidates couple only received less than 10 percent. (http://media.kompasiana.com). Nevertheless survey performed by Tempo magazine and the Lembaga Survei Indonesia estimates that Fauzi-Nachrowi and Jokowi-Basuki votes are strict. Fauzi Bowo-Nachrowi Ramli estimated to reach 44,7 percent votes. Jokowi- Ahok won 45,6 percent of the votes. There are still 9.7 percent of respondents that haven't made any choice. But estimated that Jokowi-Basuki will lose. (http://www.tempo.co).

Substantially, the various polling results of the survey agencies, television and printed media in general, show Foke - Nara candidates couple will excel in the election of the Governor of Jakarta. The prediction is not proven. Because it turns out Jokowi - Ahok supporter concentrated on younger voters, which is segmented into working group level.

Grounded to the above description, the problems of this research are: (1) What is the pattern of political communication and the characteristics of voters in the election of the governor of Jakarta period of 2012 - 2017. (2) How do the orientation of the voters if it is associated with the age of the working groups in the community. (3) What working group tends to give votes for the winning of Jokowi.

\section{Research Methods}

Research on Political Communication of Jokowi's Political Communication In Jakarta Governor Election To Win AgeBased Voters, seeks to look at the whole picture the winning of Jokowi - Ahok against Foke - Nara. This study linked the ideology of competition and political contestation between the status quo with a group that wants a change, as well as growing political opinion.

Presented by online media sites, that the local elections for Jakarta Regional Head represents opposite ideological between Jokowi-Ahok and Foke-Nara. (http://www.suaramerdeka.com). Other news stated that Jokowi-Ahok, New Reference Indonesian Politician who really fight for the people, not the interests of the status quo. (http://www.beritasatu.com). Grounded to these aspects, a study of the pattern of political communication in getting the votes based on this age group, trying to get a picture of ideology competition and forcefulness of the message that has the spirit of maintaining the status quo or change.

This study used a qualitative approach. The goal is to describe the background and the complex interaction of the participants, and to understand the circumstances that are limited in number, with in-depth and detailed focus (Bagong and Sutinah, 2011: 174). Qualitative approach, carried out with consideration able to describe, or explain the data collected, without any intention to make a conclusion that applies to the public. Proposed by Nazir (2011: 54), a descriptive study was intended to create a description, picture or illustration in a systematic, factual and accurate, regarding the facts, properties and relationships of investigated inter-phenomenon.

Source of research data, coming from various online media searching that are associated with Jokowi - Ahok, and Foke - Nara campaign patterns from various news sites. As already known that Jakarta gubernatorial election is very 
interesting to the mainstream media and the alternative media. Based on Kompas.com data related to "Jokowi - Ahok's" campaign, from the beginning of January 2012 up to the year of elections on September 20, 2012 there were 181. 811 posts. (http://search.kompas.com). While the article in kompas.com related to "Foke - Nara" amounts to 178.570 articles. (http://search.kompas.com)

Maybe another news portal showed the same symptoms, but the study only cites Kompas.com. With consideration as news portal belonging to the Kompas daily news portal that has the largest number of readers in Indonesia. (http://www.anashir.com). Kompas.com initially as the Internet edition of Kompas newspaper in the form of Kompas Online in 1995. Furthermore, in 1998 transformed into Kompas.com. In 2008, there were 20 million active readers each month, and a total of 40 million page views / impressions per month. Currently, Kompas.com has reached 120 million page views per month.

\section{Result and Discussion}

\subsection{Political Communication Pattern and Voter's Characteristics}

Perspecting from the support of political parties bearers, there are two major competing poles, Foke - Nara in governmental coalition group under the control of the Democratic Party (PD). While Jokowi - Ahok, in opposition consisting of the Partai Demokrasi Indonesia Perjuangan and Partai Gerindra. But already very prevalent, political party supporters did not have a significant influence in local elections.

Outside aspect of political parties support, the two candidates that have a distinctive pattern of political communication in exploring a symbol of success in the pursuit of government and society. Foke - Nara has a long history in the affairs of state. Therefore, it is common that in the bureaucracy's power perspective, they are seeded. Bureaucracy is synonymous with the conventional tradition of abiding to the terms, gradual organizational communication structure and linear down to the lowest level in the body of state power.

In terms of upholding diversity, Foke graduated from the Faculty of Engineering, University of Indonesia, has decent value pluralism. Leading various Muslim organizations, members of the Board of Trustees of the Democratic Party, educated from elementary school to high school at Canisius Catholic School in Jakarta. No less than Foke reputation, is Nara. The rank of Major General of TNI, experienced in the organization of the army, particularly the task of state intelligence. The civilian - military couples, tend to use one-way political communication that intentionally delivers stimuli to evoke responses of others (Wenburg and Wilmot in Mulyana, 2005: 61). In general, one-way communication is the process whereby an idea is transferred from the source to the recipient by intention of changing their behavior.

Meanwhile, Jokowi-Ahok, though appraised by government bureaucrats lack of experience, but has a uniqueness that can win the election for governor of Jakarta. Jokowi political career often presented short, simple and interactive. Furniture entrepreneurs graduated from the Faculty of Forestry, Gadjah Mada University are the Mayor of Surakarta (Solo), Central Java province, which is considered successful. While Ahok is a graduate of the Faculty of Mineral Engineering Trisakti University was not much exploring of experience in the executive and legislative branches.

Jokowi was judged to be lesser voice to favor themselves. Even when a flat inclined without affecting the mass rally in front of the public. Therefore, the messages that cornered Jokowi or slander without factual support, are also easily grown in the media. In line with the slander to the officials, Chen and Ang (2008: 73) argues, defamation cases involving government officials is the fourth wave of acts of defamation, after wave, acts of defamation by the media, society in general and the company. In other words, defamation of officer tends to be trends in the dynamics of political competition and business.

Based on the assessment of Kompas daily newspaper (June 27, 2012), Jokowi character does not dominate the conversation, and were more likely to give other people the opportunity to express their opinions in the interaction and communication done. According to Wenburg and Wilmot (in Mulyana, 2005: 65), "communication as an interaction, a process of cause - effect, action - reaction, which turns its direction. Associated with communication patterns of JokowiBasuki, the couple did not dominate the conversation in the campaign. Although actually have more opportunities to deliver messages to prospective voters.

In essence Foke - Nara couple more often express their experience within the government in one way communication. While Jokowi-Ahok not too aggressive revealed activity in the government but will listen more to the people than the speech to favor themselves. Patterns of political communication and campaign explored by two couple of Jakarta governor candidate on the second round, actually could be analogous to a war between generations based on the age of the working group, has a different character.

Referring to the opinion of Stephen Robbins (2002: 168), there are four dominant values in the working age group 
in the contemporary society, namely:

1. The Protestant Work Ethic, with the character of hard work, conservative and loyal to the organization or favor the aspect of employment as bureaucratic formalism ideal. The working group is made up of people aged 55 years to 75 years

2. Existential, oriented to improvement of quality of life, do not stick to the norm, seeking autonomy and loyalty to himself. The character inherent in those aged 40 to 54 years.

3. Pragmatism, focus on success, achievement, ambition, hard work and loyalty to a career. Consists of a working group aged 30 to 39 years.

4. Generation $X$, whose character is the inherent flexibility, job satisfaction, have enough spare time, fidelity in relationships. They are made up of people aged 30 years and under. In other literature, this group called Generation Y. As the millennium generation, they have a dependence on communications technology. However, this article mentions as generation $X$

Four dominant values attached to the working group, can be used to assess the character of the candidate of Governor and Deputy Governor of Jakarta in Jakarta gubernatorial election of 2012.

Based on data from the Regional Election Commission (Election Commission) Jakarta, the number of citizens registered as voters were 6.962.348 people (http://kpujakarta.go.id). Of this amount, if converted into a percentage of the age group based on data from the Central Bureau of Statistics in Jakarta, the composition of voters are as follows:

1. Age 55 to 75 years of age, which is included in the conservative working group and loyal to the organization, amounted to 1.044 .352 voters (15\%).

2. Age 40 to 54 years, representing the Extential Working Group total of 1.879 .833 voters (27\%).

3. Age 30 to 39 years were included in the Pragmatics Working Group Pragmatism total of 1.183 .599 voters $(17 \%)$

4. Age 17 to 29 years can be categorized in the Generation X Working Group, total of 2.854564 voters (41\%).

If look at the data of voters in Jakarta General Elections Commission, the largest number of voters between the ages of 17- 29 years (41 percent). Another voters that also still young are those aged 30 - 39 years (17 percent). Thus the votes of these two groups have strong decisive support the victory in the election of the Governor of Jakarta.

In communication between individuals and groups, there is a tendency that, the attractiveness of humans to communicate influenced by various similar aspects. According to Tubb and Moss (2008: 185-189), the cornerstone to interact and communicate among other things include (1) proximity, (2) similarity, (3) Elation reciprocity, (4) Situation in communication.

Proximity or geographic proximity, suggesting that the two geographically close persons, the greater their tendency to be attracted to each other. While the similarity (similarity), appeals to a more intimate relationship. As the basis for the relationship, the attract to human relations reinforces. The more similar the communication parties, the more effective the communication between them.

On the other hand, perceived reciprocal affection is a balanced response between the sender and recipient that can build a more cohesive relationship. Given the interaction and communication can not be separated from the situational aspects, the situation of the communication between the sender and receiver of the message also plays a role in enhancing relations to a better direction.

During a visit to the community and prospective voters, Jokowi - Ahok, trying to build a close relationship, through transactional communications, which conducted cooperatively. According to Barnlund (in West and Turner, 2008: 14) states, transactional model of communication (transactional models of communication) is the communication that occurs between the sender and the recipient that are on-going in an episode of communication and cooperative. On various occasions visited the community, Jokowi - Ahok open talks with allowing opportunity in egalitarian situation, listen and concluded as expected by the audience.

\subsection{Voters Orientation based on Working Group Age}

Associating with the opinion of Tubb and Moss, particularly with regard to similarity as an attraction, then the character of the age group, have a role in developing an understanding of communication that is capable of creating shared meaning. Therefore, the capital's residents aged 55 years and over, which amounted to 1.044 .352 inhabitants, or (15 percent) of the total voters as a potential mass for Foke- Nara couple.

Foke (64 years old) who often explores his experience in government agencies, and Nara (61 years) who regularly expose his gait in the army, has similarities with the work groups that favour the Protestant ethic working group which support for bureaucracy and formalism in the organization. (Komunitas Suara Jakarta, 2012). Therefore it is not strange if 
Foke excel in an environment of political loyalists bureaucratic and conservative groups that rely on paternalistic structure basis in legal leadership.

While those aged 40 to 55 years, numbered 1.879 .833 inhabitants (27 percent), including in the Extential Working Group, which is dominated by well-established middle class, more accepting Jokowi - Ahok which did not effacing involvement in state power and has a campaign program humanizing human, to improve socio-economic conditions.

The model of campaign is not much explored promises, but more listening to people's expectations, then the earthy appearance, Jokowi - Ahok instill stronger influence in the extential working group which are very rational. Particularly for Jokowi, according to Hafiyah et al (2012: 37), "his figure is loved by the media and praised by audiences as mayor that changed Solo character". He changed the bureaucracy, pay attention to micro-economy, improve the layout of the city, "to mend" according to community needs in education and health care, to form a strong "brand" for the city he lead. This kind of approach is attractive for constituent in the US Presidential election in 1996, in line with made by Bill Clinton to the famous campaign program with more "listening" than speech (Tubb and Moss, 2008: 25).

Seeing such illustration, then the issue of support becomes very complex. Who will emerge as the winner is not limited to the sound of success as outlined in the political campaign ads, but can not be separated from the campaign that give positive meaning to the voters were segmented into groups based on age and employment characteristics. After all Jakarta residents can not escape from the group-oriented categorization working work, productivity and material achievement in all sectors of life.

Character of recipient of the message has become very important in order to influence them to make their choice. According to David Berlo (in Ruben, 1992: 33), the process of delivering an effective message if the message is well organized through the channel of adequate and most important note is the character of the message recipient that includes the ability to communicate, attitude, knowledge of the issues presented, the social system which became a reference and culture. In this context, two candidates couples for Governor and Deputy Governor of Jakarta, the recipient must be able to 'understanding the character of the message conveyed in the campaign.

Associating with the opinion of Berlo, meaning those who choose Foke - Nara and Jokowi - Ahok, segmented into age-related similarity equation attitude. Simply said, the working group of conservatives tend to choose Foke - Nara. While the Pragmatics Working Group more inclined to Jokowi - Ahok.

\subsection{The Support of Younger Group as The Key of Jokowi's Winning}

In the second round of Jakarta gubernatorial election, there are two working groups that are the most decisive for victory, namely the Pragmatic Working Group aged 30-39 years amounted to about 17 percent and the X Generation Working Group aged 17- 29 years, amounting to 41 percent. If Foke - Nara supported by many political parties, certainly not a guarantee of winning competition Jakarta gubernatorial election. Because the most important thing is how to influence the political orientation of pragmatic and $\mathrm{X}$ generation group, in order to give votes

Responding to the existence of two groups, Foke - Nara and Jokowi - Ahok candidates couples, faces severe challenges in the political communication strategies that can convince young voters to become constituents. The main obstacle, of course, is not easy to communicate the efforts to build Jakarta, if the parties that are exploring programs and citizens as recipients of the message, has a different character segmented in the working age group.

The working group based on age, also has its own distinct language understanding with other more senior age groups. In this context, Kumju (2013: 15), stated that the language barrier makes communication less intensive, inhibiting pass collaborators in exchange and gather organized information. In addition, the communication barrier reduces the efficiency of informal communication in building the organizational as well as personal relationships.

The Pragmatics Working Group are dominated by their rational and aged 30-39 years with success orientation, the pursuit of achievement, ambition, hard work and loyalty to a career. Therefore, the rhetoric of resemble sweet promises to the rational pragmatics group, will not be ignored. Because they still see traffic jam, street crime and arrogance apparatus disturbing their ambition and their careers.

Organizing a message to the pragmatism working group, not an easy task, because it has its own culture that is no longer bound by ethnic grouping but the productivity of the group within the organization. Citing the opinion of Marcinkowski et. Al (2013: 63), " in the organization's professionalism, cultural differences are not easy to be found". Thus, the pragmatics working group is not concerned with the campaign messages in order to explore the Betawi (native Jakarta) became governor. For those who enjoy hunting for working comfort, it will be linked to the factual aspects, not the factor of ethnicity and stereotypes gossip, which campaigned by Foke - Nara Team as the original Jakarta that eligible to win.

It could be the issue of ethnicity affect the small group but it's hard to be great in a pluralistic society. Ferretti (2008: 
96) argues, "informal flow of information, such as gossip well known as efficient in small communities, but in the wider community more confidence in the formal mechanisms". Facing the Pragmatics Working Group, Foke - Nara couples unable to convince them because they understand the problems of Jakarta that have led by Bowo during the previous five years. On the other hand, Jokowi - Ahok more flexibility to gain sympathy by listening to the problems faced by the working group of 30-39 years old. In other words, pragmatic group votes tend to choose Jokowi - Ahok compared to Foke - Nara couple.

While the X Generation Working Group, which consists of people aged under 30 years are flexible, eager for job satisfaction, have free time and fidelity to the relational value of the group. Grounded to the categorization of contemporary grouping, then $X$ Generation grew up in a difficult situation of freedom of communication through messages domesticated ideal campaign promises. They are also haunted by the senior age allergies that are commonly stiff and interfere with the freedom of expression and freedom of communication of young people.

Young voters in the corridors of $X$ Generation are the biggest amount in Jakarta gubernatorial election, missed the availability of jobs that can give satisfaction and well-being. Not a problem that will be easily resolved through rhetoric pack ideal message. Because their lives have been shaped by global communications product which requires the government to provide welfare and true happiness in the state life.

Votes of young children under aged 30 years will determine the election victory of Governor of Jakarta. The group is always looking for happiness, life balance and rational. In the context of political interaction, they are much less willingness to make sacrifices to prospective leaders who have the power distance with the younger generation. Because the main priority is a natural relationship, true friendship, happiness and pleasure in living in a prosperous society.

If you look at the character of the $X$ generation aged under 30 years, the pattern of political communication explored by Foke - Nara were difficult to accept. They ignored the campaign messages that resemble the ideal message of greatness physical growth of Jakarta. Because the working age group with the greatest number, is a rational younger generation, who grew up in an atmosphere of political reform, supported by the strength of communications technology that express democracy and the availability of adequate employment. Indeed, according to Kahne et. Al, (2012: 2), the traditional measures of political participation of young people, low compared to all age groups. But those involved intensively using of digital media, such as social media, blogging, video games, and smart phones. Through these communication technologies, these young children know the political problems concerning Jokowi - Ahok.

Jokowi-Ahok political communication patterns which explores the message to young people is often done with transactional achieving a common meaning with young voters. Even through song composition by One Direction, a group of British-Irish male singers, titled "What Makes You Beautiful", the couple who supported by the Partai Demokrasi Indonesia Perjuangan and Partai Gerindra, more embed their strength in the young generation. Can not be excluded a music group consisting of Niall Horan, Zayn Malik, Liam Payne, Harry Styles and Louis Tomlinson was very popular during the election campaign of the Governor of Jakarta.

However, another important factor that can not be ignored is an informal protocolled approach and far from the influence of official behaviour. This pattern easily influence the younger generation to participate in give votes for Jokowi Ahok as Governor and Deputy Governor of Jakarta.

In other words, as stated by the definition of communication by Hennink et.al (2014: 32), that the communication is able to provide awareness to the general public for the sake of participation. Essentially communication patterns of Jokowi - Ahok more effective in influencing pragmatic working groups under the age of 30 years and $\mathrm{X}$ generation aged 17- 30 years old. According to Goyer (in Tub and Moss, 2008: 23), "Effective communication is if the message issued by the sender to obtain feedback from the receiver as expected". Effective communication, occurred because the desired response by Jokowi - Ahok and responses provided by pragmatic working groups and $\mathrm{X}$ generations are equals. JokowiAhok's victory in Jakarta gubernatorial election second round on September 29, 2012, which gained 2.472.130 million (53.82 percent) votes as representation of effective communication in influencing younger voters.

On the other hand, Foke - Nara couple with the acquisition of 2.120.815 (46,18 percent) votes, has a difference of 351.315 (7,65 percent) votes compared to the votes for Jokowi - Ahok. Couples who initially optimistic to win in one round, because it is supported by many political parties, gain a failure in political communication with the voters because of the failure to deliver the message accurately apt to the characteristics of young voters.

This is in line with the opinion of Tubb and Moss (2008: 25), that the more the number of people who are involved in the context of the communication, the more difficult it is to determine how closely the message was well received (Tubb and Moss, 2008: 25). Related to Jakarta Regional Election in 2012, the number of political parties supporting Foke Nara, exactly difficult to organize the messages to be focused on a flagship program to convince voters. Therefore, every political party supporter left various kinds of messages, in order to indicate their presence in the Foke- Nara candidates couple side. 


\subsection{Differences in Communication Patterns Two Pairs of Candidates}

Based on the three findings of study above, substantially no difference in the pattern of political communication between governor and deputy governor couples in Jakarta gubernatorial election. As the national political barometer, Jakarta with a pluralistic society oriented to the job, then the voters are not only attracted to the promise of the campaign and the physical figure, but aspects of the track record and the pattern of political communications become a crucial consideration.

The Jakarta governor election process is also increasingly attractive, given estimates of various survey agencies that favor Foke - Nara because 70 percent of the party votes. Compared to Jokowi - Ahok that were only supported by 15 percent of the party votes. But apparently the result of Jakarta gubernatorial election, won by Jokowi- Ahok couple, with 53,8 percent, or 2.472 .130 million votes. Fauzi Bowo-Nachrowi Ramli, who obtained 46,18 percent equivalent to 2.120.815 voters.

Based on the actual results of Jakarta's gubernatorial election, means that Jokowi - Ahok couple received an additional approximately 38 percent of the votes compared to the amount of support from the bearer party which is only 15 percent. Instead Foke - Nara couple actually lose a lot of votes if it is associated with a number of mass from supporting parties approximately 70 percent.

Looking at the indication, the findings in this research can be seen briefly as the table below:

Table: Support Based on Working Group and Age of Voters

\begin{tabular}{|l|l|c|l|l|}
\hline No & Working Group & Percentage & Tendency of Support & Applied Communication Pattern \\
\hline 1 & $\begin{array}{l}\text { Protestant Ethics } \\
55-75 \text { years old }\end{array}$ & $15 \%$ & Fauzi Bowo - Nachrowi Ramli & One way Linier \\
\hline 2 & $\begin{array}{l}\text { Extential } \\
40-54 \text { years old }\end{array}$ & $27 \%$ & Joko Widodo - Basuki Tjahaja Purnama & Interactive, action and reaction \\
\hline 3 & $\begin{array}{l}\text { Pragmatics } \\
30-39 \text { years old }\end{array}$ & $17 \%$ & Joko Widodo - Basuki Tjahaja Purnama & Interactive, action and reaction \\
\hline 4 & $\begin{array}{l}\text { X Generation } \\
17-29 \text { years old }\end{array}$ & $41 \%$ & Joko Widodo - Basuki Tjahaja Purnama & $\begin{array}{l}\text { Interactive, Transactional to develop unity } \\
\text { similar meaning }\end{array}$ \\
\hline
\end{tabular}

\section{Source : Data Processing Result}

The table shows, support for Jokowi- Ahok comes from three working groups namely, Ekstensial, Pragmatic and $X$ Generation. But that does not mean every working group to provide absolute support or adding to 85 percent. Because Jokowi - Ahok votes in the gubernatorial elections in the second round of about 53.8 percent. While Foke-Nara gained 47.18 percent.

Related to the tendency of the support, then the unanimity vote obtained by Foke- Nara comes from a conservative and discipline of high organization Protestant etic working group. While the extential group is more directed to support Jokowi, because the pattern of distance communication made without power and is natural. In addition, the similarity of age factor makes pragmatics people also supports Jokowi- Ahok. It is not absolute of course, because the senior bureaucrats, who still feel as one corp, tend to give vote to Foke - Nara.

The support of voters in the extential working age group, apparently followed by the majority of voters of the ambitious pragmatics working group. In working. Jokowi - Ahok with interactive political communication patterns are willing to listen to the grievances and aspirations of the people, represented as a figure who is able to work hard, to deal with the Jakarta government with has a complex socio-cultural, economic and politics.

With a more democratic assumption in political communication, the voter age from X Generation workgroups which are flexible at work, tend to support Jokowi - Ahok. The couple is favored because of the various interactions within and the public seem to run integrative reciprocal communication. On the other hand, with the advanced transactional communications to build a shared understanding, then Jokowi - Ahok increasingly attractive to young people. Given the number of voters from the $X$ Generation working group are greatest, then this group support determined the Jokowi Ahok winning as Governor and Deputy Governor of Jakarta Special Capital Region period 2012-2017. 


\section{Conclusion}

1. Competition in Jakarta gubernatorial election in 2012, not only confront program delivered in campaign and political activity, but also competition explores symbols to attract voters in the working groups in the community. Joko Widodo - Basuki Tjahaya Purnama, using interactive political communication patterns. While Fauzi Bowo - Nachrowi Ramli duet, using one-way pattern of political communication in generating public response.

2. The exstential working group has same aged between 40-54 years old tend to support Joko Widodo - Basuki Tjahaja Purnama couple. Meanwhile, Fauzi Bowo - Nachrowi Ramli tend to be supported by a working group of the Protestant ethic aged 55 years to 75 years and over.

3. In Jakarta gubernatorial election of 2012, the Pragmatics Working Group aged 30-39 years and the X Generation Working Group aged 17-29 years is the key to victory of Jokowi as Jakarta Governor.

\section{References}

Arifin, Anwar. 2003. Komunikasi Politik, Jakarta: Published by Balai Pustaka

Bungin, Burhan. ed. (2011). Metodologi Penelitian Kualitatif. Jakarta: PT Rajagrafindo Persada

Chen, Xiaoyan and Peng Hwa Ang. 2008." Defamation Litigation and the Press in China" International Journal of Communications Law and Policy, Issue 12. Winter (pp.44-75). Yale : Luigi Russi \& Mazlum Alptekin

Ferretti, Federico. 2008. "A Historical Primer on Consumer Credit Reporting Systems : A Lesson for EU Policy Makers?, "International Journal of Communications Law and Policy, Issue 12. Winter (pp. 87-130). Yale : Luigi Russi \& Mazlum Alptekin

Hennink-Kaminski, Heidi J, Jessica Fotts Willoughby, and Dana McMahan.2014. "Join the Conquest : Developing a Campaign to Increase Participation in Clinical Research in North Carolina", Science Communication : Linking Theory and Practise, Volume 36 Number 1 (pp.3-29). Los Angeles : Sage

Kahne, Joseph, Nam-Jin Lee, and Jessica Timpany Feezell. 2012."Digital Media Literacy and Online Civic and Political Participatrion", International Journal of Communication Vol. 6 (pp.1-24). Published by USC Annenberg Press.

Komunitas Suara Jakarta.2012. No.1 Untuk 1 Putaran : Rangkuman Prestasi Fauzi Bowo Sebagai Gubernur Provinsi DKI Jakarta periode 2007-20011, Jakarta : Komunitas Suara Jakarta

Krans S and David D. 1976. The Effect of Mass Communication Political Behavior, Pennsylvania : State University Press.

Koran Tempo. 2013. Editorial, 21 September 2012

Kumju, Hwang. (2013). "Effects of the Language Barrier on Processes and Performance of Internatiopnal Scientific Collaboration, Collaborators' Participation, Organizational Integrity, and Interorganizational Relationships", Science Communication : Linking Theory and Practise, Volume 35 Number 1 (pp.3-31). Los Angeles : Sage

Marcinkowski, Frank, Matthias Kohring, Silke Furst, and Andres Friedrichsmeier. 2013. 'Organizational; Influence on Scientists' Effort to Go Public : An Empirical Investigation", Science Communication : Linking Theory and Practise, Volume 36 Number 1 (pp.5680). Los Angeles : Sage

Mulyana, Deddy.2005. IImu Komunikasi : Suatu Pengantar, Jakarta : Published by Rosda Karya

Myers, Michele Tolela and Gail E. Myers.1988. Managing By Communication, Mc.Graw Hill International Book Co

Nazir, Mohammad. 2011. Metode Penelitian. Bogor: Published by Ghalia

Nimmo, Dan. 2005 .Komunikasi Politik, Komunikator, Pesan dan Media (Translation Edition). Bandung: Remaja Rosdakarya

Nurlyta Hafiyah, Niniek L. Karim and Bagus Takwin. 2012. "Satrio Pembela Wong Cilik yang Mengubah Wajah Solo" Jakarta : Surat Kabar Harian Kompas, dated 27 June 2012

Ruben, Brent D .1992. Communication and Human Behaviour, ThirdEdition, Englewood Cliffs, New Jersey : Prentice Hall.

Schramm, W. 1955. How Communication Works. In W. Schramm (Ed.). The Process and Effects of Mass Communication. Urbana: University of Illinois Press.

Susanto, Eko Harry. 2010. Komunikasi Manusia : Esensi dan Aplikasi Dalam Dinamika Sosial Ekonomi Politik "Menduga Pemenang Pilkada Jakarta oleh Eko Harry Susanto, Kompas, 3 August 2007", Jakarta : Published by Mitra Wacana Media

Suyanto, Bagong and Sutinah. 2008. Metode Penelitian Sosial: Berbagai Alternatif Pendekatan. Jakarta: Kencana

Robbins, Stephen P. 2002. Organizational Behavior, atau Perilaku Organisasi, translation Hadyana P, Jakarta : Prenhalindo.

Rush, Michael and Phillip Althoff. 1997. An Introduction to Political Sociology, atau Pengantar Sosiologi Politik,terj. Kartini Kartono, Jkt: Rajawali Pers.

Tubbs, Stewart L and Sylvia Moss 2008, Human Communication; Konteks - Konteks Komunikasi, Buku I dan Buku II, translation Deddy Mulyana and Gembirasari, Bandung : PT. Remaja Rosda Karya

Varma, SP. 2003. Teori Politik Modern. Jakarta: PT. Raja Grafindo Persada

Venus, Antar. 2004. Manajemen Kampanye. Bandung: Published by Simbiosa Rekatama Media

West, Richard and Lynn H.Turner. 2008. Teori Komunikasi : Analisis dan Aplikasi, Jakarta : Published by Salemba Humanika. 


\section{News Articles}

http://kpujakarta.go.id// accessed on 3 September 2010.

http://news.detik.com/read/2012/04/08/135453/1887188/10/survei-Isi-foke-unggul-di-pilkada-dki-disusul-jokowi, accessed on 10 October 2013)

hhttp://megapolitan.kompas.com/read/2012/ 07/19/1721403/ jokowiahok. Pemenang.Pilkada.Putaran.Pertama, accessed on 10 October 2012).

http://sidomi.com/ 131361/hasil-pilkada-dki-jakarta-2012-putaran-2-jokowi-menang-pilgub-dkil, accessed on 25 October 2013)

http://megapolitan.kompas.com/read/2012/07/01/14452150/LSI, accessed on 4 January 2014).

http://otomotif.kompas.com/read/2012/05/05/15491323/137, accessed on 5 January 2014.

http://media.kompasiana.com/new-media/2012/06/26/1fauzi-nara-pasti-1-putaran-472517.html, accessed on 27 December 2013).

http://www.tempo.co/read/news/2012/09/17/ 083429964/Survei-Foke-Versus-Jokowi-Kalah-Tipis, accessed on 26 March 2014.

http://www.suaramerdeka.com/ v1/index. php/read/cetak/2012/ 08/13/195763/Janganlah-Pilkada-Jadi-Perang-Ideologi, accessed on 2 September 2013).

http://www.beritasatu.com /blog/nasional-internasional/1900-jokowi-ahok--referensi-baru-politisi-indonesia.html, accessed on 4 August 2013).

http://search.kompas.com /fq/?q=Kampanye+Jokowi+-+Ahok+Januari+2012+-september+2012\&sort= time \& sortime= 0\&siteid=0\&startdate=\&end-date=\&lipsus=None\&sort=score, accessed on 28 October 2013) .

http://search.kompas.com /fq/?q= Kampanye+Foke+-Nara+januari+2012-+September+2012\&sort =time\&sortime= 0\&siteid=0\&startdate=\&end - date=\&lipsus=None\&sort=score. accessed on 28 October 2013).

http://www.anashir.com/2012/07/12/172156/10-situs-berita-terpopuler-di- indonesia, accessed on 11 January 2013). 